IZA DP No. 7696

Internationalisation of Education and

Returns in the Labour Market

Jacques Poot

Matthew Roskruge

October 2013

Forschungsinstitut zur Zukunft der Arbeit Institute for the Study of Labor 


\title{
Internationalisation of Education and Returns in the Labour Market
}

\author{
Jacques Poot \\ University of Waikato \\ and IZA \\ Matthew Roskruge \\ University of Waikato
}

\section{Discussion Paper No. 7696 \\ October 2013}

\author{
IZA \\ P.O. Box 7240 \\ 53072 Bonn \\ Germany \\ Phone: +49-228-3894-0 \\ Fax: +49-228-3894-180 \\ E-mail: iza@iza.org
}

Any opinions expressed here are those of the author(s) and not those of IZA. Research published in this series may include views on policy, but the institute itself takes no institutional policy positions. The IZA research network is committed to the IZA Guiding Principles of Research Integrity.

The Institute for the Study of Labor (IZA) in Bonn is a local and virtual international research center and a place of communication between science, politics and business. IZA is an independent nonprofit organization supported by Deutsche Post Foundation. The center is associated with the University of Bonn and offers a stimulating research environment through its international network, workshops and conferences, data service, project support, research visits and doctoral program. IZA engages in (i) original and internationally competitive research in all fields of labor economics, (ii) development of policy concepts, and (iii) dissemination of research results and concepts to the interested public.

IZA Discussion Papers often represent preliminary work and are circulated to encourage discussion. Citation of such a paper should account for its provisional character. A revised version may be available directly from the author. 


\section{ABSTRACT}

\section{Internationalisation of Education and Returns in the Labour Market ${ }^{*}$}

The education services provided in any given country increasingly contribute to human capital that is employed in another country. On the one hand, graduates may seek to obtain the highest return to the knowledge they gained in their home country by working abroad. On the other hand, some students purchase educational services abroad and will subsequently work abroad, or return home to utilize the internationally acquired knowledge in the domestic labour market. In this paper we use data from the 2006-07 Adult Literacy and Life Skills survey in New Zealand to examine how years of foreign and domestic education affect earnings in the labour market. We account for differences in innate ability by aggregating subjective responses to pertinent questions in the survey and by incorporating parents' educational background. Our findings reconfirm the extensive evidence that education gained in a country of birth has generally a lower return in a foreign labour market than the native born receive in this labour market for the equivalent education. Post-settlement education in the host country has a higher return for migrants than for comparable native born. We also find that the highest returns are obtained among those who, after studying abroad, return home to work - a fact for which there has been to date scarce evidence. Thus, exposure to foreign education can lead to a triple gain: for the country where the education is obtained, for the students' home country and for the students themselves.

JEL Classification: F22, I24, J24, J31

Keywords: international education, human capital, earnings, selection effects

Corresponding author:

Jacques Poot

National Institute of Demographic and Economic Analysis

University of Waikato

Private Bag 3105

Hamilton

New Zealand

E-mail: jpoot@waikato.ac.nz

\footnotetext{
* An earlier version of this paper was presented at the Pathways, Circuits and Crossroads Conference in Wellington, December 12-13 2011 and at the special session on "Academic Knowledge Commercialization, Universities and Regional Economic Development" at the Japan Section of the Regional Science Association International (JSRSAI) $50^{\text {th }}$ Anniversary Conference, Rissho University, Tokyo, October 6-8 2012. Comments from conference participants are gratefully acknowledged. Jaimee Phillips provided excellent research assistance during Waikato University's 2010/11 Summer Research Scholarships Programme. The paper is forthcoming in Studies in Regional Science. The research was funded by FRST grant MAUX0605 (Integration of Immigrants Programme). The 2006 Adult Literacy and Life Skills Survey (ALL) dataset was provided by Paul Satherley at the Ministry of Education of New Zealand.
} 


\section{Introduction}

Education is a booming global business. Governments of many developed countries encourage their educational institutions to recruit foreign fee-paying students. These students benefit themselves from investing in human capital that tends to have a high return in the global labour market. The host region benefits from the additional consumption expenditure and the educational institution benefits from economies of scale and scope. At the level of postgraduate education, there can also be spillover benefits of training diverse foreign students for research, innovation and local industries (see e.g. Leydesdorff (2012) on the so-called “Triple Helix” model) and also economic growth (Bergerhoff et al., 2013). These benefits often prompt subsidisation of talented students through privately funded scholarships or public subsidies. Nonetheless, there has also been pronounced criticism of the internationalisation of education on the grounds that it contributes to the "brain drain" from developing countries (for a review, see e.g. Adnett, 2010). However, other research suggests that migrant-sending countries benefit through greater enrolments in their own educational institutions, facilitation of trade through networks of diaspora, return migration and remittances (see e.g. Duncan, 2008, for a review; and Gibson and McKenzie, 2012, for recent evidence).

The links between international migration, education and earnings have attracted a lot of attention in the literature (for a recent review, see Dustmann and Glitz, 2011). One aspect of this literature that has not yet received much attention is the rate of return to study abroad when working subsequently again in the home country. The majority of workers have never migrated and their education is "indigenous". Current and former migrants, however, may have been educated in one, two or more countries. It has long been established that the education of an individual plays an important role in the determination of earnings, along with innate ability (e.g. Card, 1999). An important question in this context is how the country where the education was obtained and the country of employment both affect earnings. To quantify this interaction, a researcher requires longitudinal data on where in the world, at what level and for how long a person has been educated. In a theoretical model of brain drain and return migration, Mayr and Peri (2008) note that there is only anecdotal evidence that workers with international experience may receive a significant wage premium when they return to their country of origin and that more research is needed to measure this effect. This would also apply to the foreign education of return migrants. Both Mayr and Peri (2008) and Dustmann et al. (2011) develop theoretical models of how the foreign experience and on-the-job training of return migrants may lead to a "brain gain”, but much empirical work on this is still sorely need. 
In this paper we use data from the 2006-07 Adult Literacy and Life skills (ALL) survey (n=7,131) in New Zealand to examine how the number of years of foreign and domestic education affect earnings in the New Zealand (NZ) labour market. One unique aspect of our data is that we can split the total years of education of native born and foreign born workers into education obtained in NZ and education abroad. Of course, if we find that returns to foreign education are relatively high, we must accept that this may be partially due to non-random selection of people who have benefitted from education abroad. Such people may have high innate ability and low risk aversion which induces them to migrate for work or to go abroad to study. We partially control for such sorting by explicitly accounting for differences in innate ability between workers. We also control for employment selection in the NZ labour market by means of Heckman's two-step regression procedure (see Heckman, 1979). We account for innate ability, which is usually unobserved but interacts with educational choices, by aggregating subjective responses to questions in the survey that inform on natural ability and by accounting for parents' educational background.

The case of New Zealand is of particular interest because New Zealand has an internationally very mobile labour force (for a review see e.g. Bedford and Poot, 2010). At any point in time, up to about one fifth of people born in New Zealand reside outside New Zealand (particularly in Australia), while one quarter of the population of New Zealand is foreign born. Immigration policy in New Zealand encourages foreign students in higher education to seek jobs and apply for residency in New Zealand upon graduation (e.g. Spoonley and Bedford, 2012). The data used in this paper suggest that 46.2 percent of foreign born workers in New Zealand have some NZ education, while at the same time about 4.5 percent of the NZ born have some foreign education.

In recent years there have been around 50,000 fee-paying foreign born tertiary students enrolled in NZ higher education institutions. These come from (in descending order of numerical importance): China, India, South Korea, Japan, Saudi Arabia, Thailand, Malaysia, Germany and a wide range of other countries. International students generate an economic benefit of over \$2.7 billion annually (about 1.3 percent of GDP) and support over 32,000 jobs (Education New Zealand, 2012). International education enhances the academic reputation of higher education institutions and improves the cost-efficiency of education provision. Almost one-third of fee-paying international students finds subsequently work and obtains residency in New Zealand. At the same time, many NZ graduates move overseas upon completion of their degrees simply for a "break", or to gain overseas experience, or to accelerate the ability to pay off their student loans (since NZ graduate earnings are often lower in real terms than those obtainable in popular destinations such as the United Kingdom and Australia). 
Our findings show that, for immigrants, the education gained in the country of birth has a lower return in the NZ labour market than the NZ born receive in this labour market for the equivalent education. However, post-settlement education in New Zealand has a higher return for migrants than for comparable NZ born. Interestingly, and less well established in the literature, is that the highest returns are found among those NZ born who, after studying abroad, return home to work. Thus, exposure to foreign education can lead to a triple gain: for the country where the education is obtained, for the students' home country (when such diaspora students return home or transfer remittances) and for the students themselves. We note that the internationalisation of research-based education can also yield trans-national benefits for innovation, trade and foreign direct investment (for a review, see Poot, 2013).

In Section 2 we briefly review pertinent international and New Zealand evidence on the impact of domestic and foreign education on an individual's earnings. Section 3 provides details of the data used alongside descriptive statistics summarising the variables which are used in the multivariate analysis. Section 4 outlines the regression modelling which is used to analyse the relationship between hourly wages and the location of where the education was obtained (foreign or domestic), in addition to wage determining socioeconomic variables. Section 5 provides an overall summary of findings and implications.

\section{Foreign education and earnings}

Ever since the work of Mincer (1958), a vast number of empirical studies have estimated the impact of human capital on earnings. However, there is imperfect transferability of human capital between countries. Education and labour market experience acquired abroad are often rewarded less than the equivalent domestic human capital (Friedberg, 2000). This may be related to factors such as quality of education, language and cultural differences, discrimination, year of arrival, immigration policies and length of stay in the host country (see e.g. Borjas, 2013, section 8.5, for a review). In some cases it is the credentials themselves and not the skills gained through the qualification that will determine which jobs are available and therefore the level of pay (Chiswick and Miller, 2009). Imperfect transferability of foreign credential can result from the limited information host country employers have of the quality of the education or the skills newly arrived migrants have. Hence employers may consider the recruitment of foreign workers without host country experience risky. Therefore, on entry into the host country, immigrants often work in jobs not commensurate with their level of education, receive lower remuneration for both their qualifications and labour market experience, and suffer barriers in attaining better employment (e.g. Poot and Stillman, 2010). 
One cause of earnings disparity between similarly educated foreign and native born residents is due to foreign experience being valued less. Friedberg (2000) found that native born workers can expect a 1.7 percent return for each year of domestic experience while immigrants receive in the host country a 1.1 percent return for each year of host country experience and a 0.1 percent return for experience in their home country. Pre-migration experience is an imperfect substitute for experience obtained in the host country as a result of country-specific skills that are required in numerous occupations. Therefore continuous experience obtained in the destination country earns a higher return than the same length of foreign and domestic experience combined (Fujii and Mak, 1983). Additionally, further education after migration yields greater increases in earnings among immigrants than comparable natives would obtain (Ferrer and Riddell, 2008). In addition to the disparity arising from the source country of human capital, language barriers also contribute to the earnings gap and it is important to control for this factor separately (Chiswick and Miller, 2003; Dustmann and Van Soest, 2002). The earnings differential due to foreign educational credentials becomes larger when immigrants belong to a visible minority ( $\mathrm{Li}$, 2001) or simply come from further afar (Hammarstedt and Shukur, 2006). Alongside potential ethnic discrimination there is also gender disparity. Beach and Worswick (1993) report that there is a double negative effect for female immigrants with a professional or postgraduate degree. Additionally, Borjas (1987) finds that differences in earnings between immigrants with identical skills may be due to variations in economic and political conditions in the countries of origin.

The disparity between foreign and native education premiums is often larger during the first few years after arrival and diminishes with time spent in the host country as immigrants increasingly understand the host country labour market better and gain more host country experience. Eventually, some immigrants will end up earning more than comparable natives. Chiswick (1999) explains such earnings catch up or overtaking inter alia by immigrants working harder and longer than natives. There is also sorting of workers in that the highly motivated and most able people often have the greatest incentive to migrate (assuming the occupation-specific earnings distribution in the destination country is wider than in the source country) and this contributes to the earnings of immigrants overtaking those of comparable native born residents.

Despite the importance of understanding migrant-native differences in returns to education in a country in which one quarter of the population is foreign born, empirical analysis of this issue in New Zealand has been relatively limited. Poot et al. (1988) used 1981 cross-sectional census data to investigate the economic adaption and labour force participation rates of immigrants. Following this, Poot (1993) analysed how the process of immigrant adaption was influenced by the business cycle and structural 
labour market changes over the 1981-86 period. Zodgekar (1990) focused attention on British migration to New Zealand with a particular interest in their motives, socioeconomic background, status and expectations. Poot and Stillman (2010) used census data to assess the extent of over-education and under-education of immigrants. Allen (2010) investigated the extent to which immigrants on work and study permits became permanent NZ residents and Woolf (2010) investigated the social and economic outcomes of the children of migrants.

Winkelmann and Winkelmann (1998) provided a comprehensive analysis of the impact of education on earnings of immigrants and native born New Zealanders by means of econometric modelling of 1981, 1986 and 1996 Census data. Boyd (2003) provided a partial update with 2001 and 2006 census data. Stillman and Maré (2009) used the "New Zealand Household Income" survey from 1997 to 2007 to examine the economic performance of immigrants in New Zealand. They compared employment rates, hourly wages, annual income and occupations to those of the NZ born. The 1991 immigration policy "reform", that led to a NZ focus on attracting predominantly highly skilled migrants, resulted in a number of comparative analyses of immigrants and NZ born residents, using 2001 Census data (Statistics New Zealand, 2004; New Zealand Immigration Service, 2003a, 2003b).

The results from this New Zealand research are not dissimilar to findings of the international literature. Despite NZ immigrants being on average better educated than the NZ born, they are likely to suffer an earnings disadvantage on entry into New Zealand. Winkelmann and Winkelmann (1998) estimated this to be about 20 percent relative to comparable NZ born residents. Stillman and Maré (2009) find similar evidence. Winkelmann and Winkelmann (1998) found that this earnings gap persists on average for a long period of time, with convergence of labour force participation expected to require between 5 and 15 years and income parity between 10 and 30 years. Stillman and Maré (2009) suggest that the convergence time is dependent on the education level of immigrants. They find that those with university qualifications are likely to reach a comparable level of pay within 10 years. However, unqualified immigrants reach this parity only after approximately 20 years.

NZ studies confirm the notion that language plays an important role in determining the transferability of education credentials and the overall integration of immigrants. Working age immigrants from nonEnglish speaking countries have a lower employment rate than those from English-speaking countries and NZ-born residents (Boyd, 2003). The income differential between immigrants from English speaking countries and the NZ born is relatively small. Those lacking English language fluency are at a much larger disadvantage and in some cases not expected to ever reach equality with natives (Winkelmann and Winkelmann, 1998). 
Much of the previous empirical literature compares the migrants' returns to education obtained in their home country with natives' returns to education obtained in the host country. While migrants' returns to any additional education and particularly experience in the host country are sometimes also assessed, the returns to foreign schooling of the native born are rarely incorporated in the same framework. Doing so is the objective of the present paper. Gibson and McKenzie (2011) study migratory behaviour and labour market outcomes in a survey of the brightest former students in Tonga, Papua New Guinea and New Zealand. They find that economic returns to human capital play only a minor role in the migratory behaviour of these students, but they do observe huge returns to migration and generally positive returns to return migration. However, they note that their small sample size limits the extent to which they can examine returns to different qualifications at home and abroad. In another study that also includes Ghana and Micronesia, Gibson and McKenzie (2012) find statistically insignificant income gains from return migration and they even argue that return migrants may do worse than comparable non-migrants. However, their data did not permit the direct comparison of rates of return of specific years of education by location of the education (home and abroad) that is presented in this paper. There certainly are selection effects likely to be present in return migration and it is possible that such selection depends on the level of development of the host country. Lubotsky (2007) finds that out-migrants from the U.S. are negatively selected. Soon (2012) finds that, in the NZ context, foreign born doctoral students and students from the health sciences are less likely to return home.

\section{Data and descriptive results}

This paper uses data from the NZ ALL Survey which was conducted between May 2006 and March 2007 (see also e.g. Earle, 2009). The survey collected data from a nationally representative sample of 7,131 respondents aged between 16 and 65, with a response rate of 64 percent. One eligible member from each randomly selected private household was arbitrarily chosen to partake in a face to face interview. The ALL survey collected information on: the individual's demographic and household characteristics; education; immigration status; language skills; parental characteristics; labour force activities; literacy and numeracy; participation in education and training; social participation and wellbeing; access to and use of information and communication technologies (ICT); health status; and income. Validation procedures have been undertaken against official statistics to ensure the ALL survey is a true representation of the NZ population.

For the purposes of this study the sample frame has been restricted to adults aged 18-65. To calculate returns to education, only those who received income from either wages or salary in their main occupation are included. We exclude self-employed individuals because their educational credentials are 
often not a strong predictor of earnings (Poot and Stillman, 2010). Those reporting an annual income of less than \$1,000 and those working less than 260 hours per year (5 hours per week) have also been dropped from the sample. In addition to these exclusions a limited number of observations are dropped due to missing information on either income or educational attainment. No imputation was applied. As a consequence, the sample size for our analysis of earnings is 3,419 of whom 800 (23.40 percent) are foreign born. This sample is comprised of 1,194 NZ born men, 1,425 NZ born women, 389 foreign born men and 411 foreign born women. Descriptive statistics are given in Table 1. For tests of statistical significance of differences between groups we rely on the multivariate modelling later on.

Table 1 about here

The average age of the sample was 40.15 years, with little difference across gender and birthplace. Hourly earnings (in 2007 dollars, before taxes and all other deductions) are around \$25, but more for males than for females and more for foreign born males than NZ born males (which reflects the relatively high skill levels of NZ male immigrants). The ALL survey allowed pre-tax income to be expressed in nine different ways: including per hour, per day, per week and per year. The consistency of this information was assessed and this led to defining hourly earnings as annual income divided by the number of hours the individual works per year. Income from sources such as rent, dividends or windfall profits has been excluded to allow for direct comparisons between education and income from wages or salary. Working less than 30 hours per week is considered part-time in New Zealand, therefore those earning less than $\$ 15,457$ (29 hours times $\$ 10.25$ (adult minimum wage 2006-07) times 52 weeks) have been recoded to be working part-time for the purposes of this analysis. Average hours worked per year are quite high in New Zealand: more than 2000 for men.

Once differences in hours worked and hourly earnings are taken into account, females have less annual income than males, but foreign born females have higher income than NZ born females. NZ males have roughly the same income as migrant males. Migrants are on average about 17 years in New Zealand and migrant males are less likely to have children. On the other hand, migrant households are larger than households with NZ born survey respondents. There is a somewhat greater prevalence of physical health problems among the NZ born than among migrants.

Individuals are able to report up to five ethnicities, but we used a prioritisation algorithm to assign unique ethnic identities to people (with those reporting more one ethnicity being assigned to the minority ethnicity). The ethnic composition of the NZ born sample was dominated by NZ Europeans making up 78.73 percent of the males and 80.84 percent of the females. Of the total sample, 10.62 percent are Maori (predominantly native born), 8.10 percent are from the Pacific Islands (predominantly 
foreign born), 6.52 percent are Asian (almost exclusively foreign born) and 8.36 percent are from a variety of other ethnicities (about 30 percent of the foreign born).

Native born males have on average 7.56 years of experience in the current job. Women and migrants have on average less tenure in their current job. While foreign born men are more likely to work parttime than their native born counterparts, for women it is the opposite. Those from a rural location made up 10.97 percent of the total sample, but this is much more common among the NZ born than among the immigrants.

Defining human capital is imperative for this analysis. The ALL survey asked specific information of the respondent regarding the total number of years spent in formal education. Although the ALL survey did not report the lifetime experience of the individual, age and current job tenure are used to approximate the effects of this form of human capital. An important issue is, as always, the role of innate ability vis-à-vis completed years of education, educational credentials and the environment (see e.g. Zax and Rees, 2002)). The ALL survey contains a number of questions regarding the individual's English reading, writing, math and computer skills and specifically whether respondents considered such skills to be adequate for doing their job well. Barrett (2012) shows, using the Australian ALL survey, that accounting for cognitive abilities reduces the return to an additional year of education by one third. We carried out principle component analysis with the NZ ALL ability measures and interpret the first principal component as a proxy for unobserved innate ability. The variable is recorded relative to a benchmark score of 0 for the entire sample. The average score for NZ born males is -11.34 less than this benchmark, for females 10.86 more. For foreign born males, the average score is less negative (2.17), which is consistent with the principal applicant in migration decisions (who is often male) being positively self-selected. However, the innate ability score is much more for NZ born females (10.86) than for migrant females (0.70).

In addition to generating this ability score, the ALL survey also includes information about the education of the parents of an individual. This may affect the children's schooling decision. It may also convey information on how nature and nurture together influence the individual's abilities (Holmlund et al. 2011). To keep matters simple, we merely measure whether either the mother or the father, or both, have post-secondary education. Post-secondary education is much more prevalent among parents of the foreign born than parents of the NZ born: close to half of female migrants has a father with postsecondary education. For NZ born females this is only 32.91 percent. To account for selection effects in employment, we also measure in our regressions later on the extent to which an individual earns investment income or receives some form of social security. About one quarter of the sample receives 
investment income. Social security is less likely to be received by migrants. This is not surprising since eligibility usually requires at least two years of residency. Finally, we follow the conventional labour force participation literature by positing that household size has a negative impact on an individual's likelihood of being employed, but only for women. Household size is slightly larger for foreign born women than for NZ born women.

Table 2 presents detailed information about the schooling characteristics of the NZ born and immigrants, including the years of total education and the highest level of schooling attained. Examining the total number of years spent in formal education, it is evident that there is little difference between genders. The difference between NZ born and immigrants is relatively small, but immigrants have spent longer in a place of formal education than NZ born. As noted earlier, this reflects New Zealand's immigrant recruitment policies that are heavily skill oriented. On average, male immigrants have spent 14.26 years in formal education. This equates to the completion of secondary school and a post-secondary certificate or diploma. NZ born males have spent an average of 13.23 years of formal education, only equivalent to the completion of secondary school. Females follow a similar pattern to males, with female immigrants having spent 1.19 years longer in formal education than NZ born females.

\section{Table 2 about here}

Figure 1 displays the distribution of total years of education for the NZ born and for the foreign born. The Figure clearly shows that many foreign born are better educated than the NZ born, with much of the immigrant distribution being to the right of the distribution for the NZ born. When we disaggregate years of education by the location of that education (NZ or abroad) we find that 3.85 percent of NZ born males and 4.98 percent of NZ born females have some foreign education. Conditional on having positive foreign education, NZ born males have about 4 years of education abroad. For females, this is less (2.86 years). The vast majority (more than 80 percent) of the foreign born arrive in NZ with foreign education, of course predominantly education gained in the country of birth (we cannot identify education obtained in third countries). However, close to half of the foreign born have some NZ education, and those who do spent about 8 years in the NZ educational system.

Figure 1 about here

The comparison of highest level of schooling attained for the NZ born and foreign born is entirely consistent with the difference in total years of education discussed above. 16.97 percent of foreign born males have a postgraduate qualification, for NZ born males this is only 6.53 percent. For post-secondary 
undergraduate qualifications, the percentages are in aggregate similar for migrants and the NZ born (around half) but, within this group, the foreign born are overrepresented at the university degree level, whereas the NZ born dominate in polytechnic type certificates as levels 1 to 4 .

One caveat with the available data is that the sequencing of the NZ and foreign education is not known explicitly. However, it is reasonable to assume that the majority of the NZ born who also experienced education abroad had their NZ education first (e.g. primary and secondary education) and their foreign education subsequently (e.g. tertiary education). In contrast, for the foreign born it is reasonable to assume that their foreign education preceded their NZ education. Given that returns to education may diminish with increasing years of education (e.g., Borjas, 2013), knowing the sequencing of domestic and foreign education is important for the interpretation of the differences in education coefficients in earnings regressions. We will return to this issue in the next section.

\section{Multivariate regression analysis}

In order to test the impact of internationalisation of education on the human capital returns of individuals, we start with standard Mincer earnings regressions, estimated by ordinary least squares (OLS), in which the natural logarithm of earnings is regressed on age, age squared and total years of education. We also allow for differences between the NZ born and migrants, while years since migration is an additional regressor for the latter (Chiswick, 1978).

The results can be found in Table 3. The estimated return of one additional year of schooling is 6.2 percent on average. However, the return to an additional year of education is greater for females than for males: 6.9 percent versus 5.7 percent respective. The relationship between age (which proxies for labour market experience) and earnings has the usual concave shape. ${ }^{1}$

Immigrants are found to earn significantly less on arrival than natives, despite the fact that they are on average higher educated than the NZ born. Male immigrants are found to earn 11.4 percent less on arrival than NZ born males. Interestingly, this effect is stronger for females, with female immigrants earning 19.5 percent less on arrival than their NZ born counterparts. The negative earnings effect for immigrants on arrival to New Zealand may be due to a number of factors. Firstly, immigrants may have a lower reservation wage than the NZ born. Secondly, immigrants can be disadvantaged by

\footnotetext{
${ }^{1}$ It can be easily calculated that earnings peak around age 50 .
} 
discriminatory hiring practises in NZ workplaces. Their labour market outcomes may also be a result of inadequate job networks and having skills that are not transferable to the NZ labour market.

Table 3 about here

The larger wage difference on entry for female immigrants may be due to females not being the primary applicant for immigration into New Zealand. Female immigrants may be "tied movers" in which the most favourable option for the family (migration) may not be the best option for the female (Borjas, 2013). As a result of being a "tied mover" females will gain access to New Zealand through the family sponsored stream of NZ immigration policy. Due to being a tied mover female immigrants may lower their wage expectations and therefore have a lower reservation wage than NZ born natives.

Although immigrants on arrival earn less than NZ born, their relative earnings increase with each year spent within New Zealand. The "catch up" effect is around 0.4 percent per annum, but it is not statistically significantly different from zero for males (but close). The "catch up" reflects both positive selection of immigrants on unobservable personal traits as well as returns to labour market experience in New Zealand.

Table 4 expands the previous analysis by splitting total years of education into years of NZ education and years of education abroad. Additionally, the number of years in the current job (which tends to reflect job-specific on-the-job training) is also taken into account. Furthermore, the coefficients of observed human capital variables can be biased if unobserved ability positively affects educational outcomes as well as current earnings. One of the very attractive features of the ALL survey is that it contains information that allows us to calculate an innate ability score for each individual, as discussed in the previous section. The measure of innate ability has been included in the regressions reported in Table 4. In addition, each regression also controls for the location of the household (urban or rural), the industry in which the person works, the presence of children, health status and the education level of parents. For simplicity, the coefficients of these control variables are not included in Table 4.

Table 4 about here

Comparing Tables 3 and 4, we see that the effects of being foreign born and years since migration still have the expected signs, but are no longer statistically significant in Table 4. The effect of age is similar in the two sets of regressions. With respect to education, it is clear that human capital obtained abroad is valued significantly less than domestically obtained human capital. The return of one year of NZ schooling for males is 2.6 percent (after controlling for innate ability differences, etc.) while for each year of education obtained abroad the return for males is 2.5 percent. The returns to education available 
to females are higher than those of comparable males, and again foreign education is valued significantly less than NZ education. One year of NZ schooling for females yields a 4.6 percent return while the return to education received abroad is lower at 4.2 percent. This result confirms the hypothesis that education obtained in a foreign country has a lower return on average in comparison to domestic education. However, no distinction is made as yet between migrants and the NZ born in that respect (this distinction will be made in Table 5 below). ${ }^{2}$

Tenure, defined as the length of time the individual has been in the current job is a significant predictor of hourly wage. The return to tenure is stronger for males than for females: 1.2 percent for each additional year within the workplace versus 0.9 percent respectively. The measure of innate ability (a composite measure of the perceived level of reading, arithmetic and computer skills within the workplace of the individual) has a positive impact on earnings, as expected, but the effect is statistically insignificant for females. Using the pooled data, introduction of the measure of innate ability reduces the return to years of additional education from about 6 percent (Table 3) to about 4 percent (Table 4), a very similar result to what Barrett (2012) found for Australia.

The results reported so far show that, on arrival, immigrant skills are undervalued and foreign education is found to be valued less than NZ domestic education. As a result, immigrants are often overqualified for the position that they are in and are therefore not receiving the level of income that they should as a result of their education. This waste of skills is detrimental for the NZ economy, as better job matching of immigrants would allow for increased efficiency and subsequently increased productivity. However, immigrants may partake in learning activities in New Zealand that may enable them to be eventually on equal footing with the NZ born. One way for an immigrant to adapt their former education and training to be suitable within New Zealand may be to invest in NZ education after arrival. By adding NZ human capital to their current foreign human capital they may aid the transferability of their skills and essentially “catch up” with NZ born natives.

Table 5 reports regressions of the relationship between the log of hourly wages and human capital attainment in New Zealand and abroad, separately for immigrants and NZ born. Males and females have been aggregated in order to keep the sample sizes large enough, but this is not expected to significantly impact the overall findings. In these regressions we also account for the fact that the earnings that are observed in the ALL survey may not be a random sample of earnings available to the population. To

\footnotetext{
${ }^{2}$ While the rates of return to education are all statistically significantly at the 5 percent or 1 percent level in Tables 4 and 5 , the statistical significance of differences between these is hard to establish given the limited sample sizes. Thus, the reported differences remain tentative only but they are at least consistent with the theoretically expected effects.
} 
control for systematic selection into employment and related bias in estimating returns to education, we use Heckman’s (1979) two step procedure.

Table 5 shows that the coefficient of lambda (the inverse Mill's ratio) is statistically significant for both the NZ born and the foreign born. It is interesting that the coefficients are negative. This suggests that there is a negative selection effect. We find indeed that the bias-corrected returns to education are lower than those that would have been obtained with OLS (results available from the authors upon request). What could be responsible for such negative selection? We suspect that, given the nature of the ALL life skills and literacy survey, considerable effort was made to recruit into the survey sufficient numbers of people with limited literacy and numeracy skills who, nonetheless, were in employment.

The sample selection model is only effective when there are a number of variables that determine selection but that are assumed to have no direct impact on earnings (the exclusion restriction). We consider four such variables. The first one is a dummy variable that measures whether a person receives private investment income (interest, dividends, etc.). While labour supply theory suggests that the amount of such non-wage income affects a person's reservation wage, the dummy variable is not expected to have such a direct impact itself. Secondly, we introduce an interaction variable that is the product of the dummy variable "gender” (equal to one for females) times household size. This variable takes into account that labour force participation of women, but not of men, is inversely related to household size. Receipt of social security is also expected to (negatively) influence labour force participation. Finally, we include several ethnicity dummy variables.

\section{Table 5 about here}

Table 5 shows that these selection variables operate quite similarly for the NZ born as for the foreign born. Receipt of investment income or social security both lower the chance that labour market earnings are observed for a person. Larger household sizes also lower the probability that women are working. The ethnicity variables are insignificant for those of Maori and Pacific Island ethnicity, but it does appear that being Asian lowers the employment probability of the foreign born, while being of "other ethnicity” lowers this probability for both NZ born and foreign born.

Table 5 shows that males generally earn more than females, as expected. However, the gender gap is smaller among the foreign born (0.103 versus 0.139$)$. Interestingly, the foreign born earn more in rural areas. This is plausible given that most immigrant labour supply is in cities. Household size has no direct effect on earnings, but affects employment selection of women negatively as noted above. Ill health lowers the likelihood of employment, as expected, but NZ born who have ill health but are still 
working are in receipt of earnings 5.9 percent more than otherwise. Age has the conventional concave relationship with earnings and employment, as expected.

The returns to tenure are slightly more for the foreign born: 1.2 percent per year versus 1.1 percent. The proxy for innate ability and the post-secondary education of the father both increase earnings of the foreign born. These variables are not statistically significant for the NZ born.

Finally, Table 5 informs on the monetary benefit of obtaining education abroad. We take the impact of years of NZ education on earnings of the NZ born as the benchmark. The real rate of return (once accounting for innate ability, parents' education, etc.) is 2.4 percent. This is higher than the return which the foreign born receive for their years of education undergone abroad (1.8 percent). However, as expected, education in New Zealand has a significant return for the foreign born (2.8 percent), which is in fact greater than that for the NZ born. As was noted in the previous section, it is highly plausible that these NZ years of education were the migrant's final years of education. At the same time, the years of NZ education of the NZ born most likely preceded their education abroad. Given the possible diminishing returns to additional education, this implies that the observed NZ born versus foreign born differences in rates of return to education are likely to be underestimates of the true differences. ${ }^{3}$ The highest returns to education are obtained by the NZ born who return to the NZ labour market after having had one or more years of education abroad (3.3 percent). It could be argued of course that this return to foreign education is based on selection effects. While it is plausible that those who go abroad to study are positively self-selected, it is also possible that those who return to work in the home country may be negative self-selected as the most successful migrants may remain abroad. In any case, measures of ability and background (parents' education) are included in the regression so such selection effects are to some extent accounted for. Additionally, return migrants may be characterized by having a high preference for the non-pecuniary benefits of home country amenities, personal networks and values. This is another factor that suggests that the return to foreign education for the NZ born in the NZ labour market as calculated in Table 5 may be an underestimate of the genuine benefits of foreign education.

\section{Conclusion}

This paper has examined the returns to foreign and NZ domestic education by means of data from the 2006-07 Adult Literacy and Life Skills survey. Our findings reconfirm that, for immigrants, the

\footnotetext{
${ }^{3}$ However, quadratics in years of NZ and foreign education added to the regressions in Table 5 were not statistically significant. These results are available from upon request from the authors.
} 
education gained in the country of birth has a lower return in a foreign labour market than the native born receive in this labour market for the equivalent education. However, post-settlement education in the host country has a higher return for migrants than for comparable native born. Interestingly, the highest returns are found among those who, after studying abroad, return home to work.

NZ born people receive a return of between 2.4 percent to 5.8 percent (dependent on the model specification) for every year of NZ education. Compared with the NZ born having NZ education, foreign born receive an additional 0.4 percentage point return for every year of NZ education. However, compared with the NZ born having NZ education, the NZ born receive an additional 0.9 percentage point return for every year of foreign education.

The observed differences in returns are imprecisely estimated and may still be partially due to unobserved "selection effects" that "sort” the population into migrants and non-migrants (even though ability is measured directly). In theory, one could look for pseudo-experimental methods (for example: studies of identical twins of whom one of the two obtains foreign education; Propensity Score Matching methods; and natural experiments) to generate unbiased estimates of the return to foreign education. However, such empirical designs are often difficult to implement (for example, scholarships for foreign education are rarely assigned randomly among applicants).

Nonetheless, the results of the present paper suggest that policies that facilitate international students' staying on in New Zealand have been important in attracting such students and also provide an avenue to obtain skilled migrants, as many such students apply for work and/or residency upon graduation. Research shows that former international students perform well in the NZ labour market and have high rates of settlement and satisfaction with their life. In general terms, former international students who gain a bachelor's degree or higher qualification in New Zealand achieve better labour market outcomes than those who gain lower-level qualifications. Specifically, subsidising foreign $\mathrm{PhD}$ students is an effective means of expanding university research \& commercialisation. Thus, exposure to foreign education leads to a triple gain: for the country where the education is obtained, for the students' home country and for the students themselves. The internationalisation of research-based education can also yield trans-national benefits for innovation, trade and FDI.

Finally, New Zealand also needs new policies to encourage the return of some of the 0.75 to one million NZ citizens who are estimated to live abroad. According to the OECD, the percentage of university graduates among NZ diaspora is higher than among other developed nations (Dumont and Lemaitre, 2008). While the issue whether foreign education should be encouraged is complex due to domestic and foreign education externalities, diaspora networks and the selectivity of return migration, the results of 
this paper suggest that policies that encourage return migration of NZ born with foreign experience and foreign education could have significant pay-offs. Additionally, for many NZ researchers the inclusion of a period of work broad is common, with the expectation that such a stay will develop their international standing and the peer linkages required to support a career back in New Zealand. The intensification of international linkages in education and research through the mobility of students and researchers clearly benefits both sending and receiving countries. 


\section{References}

Adnett, N. (2010). The Growth of International Students and Economic Development: Friends or Foes? Journal of Education Policy 25(5): 625-637.

Allen, K. (2010). Transition to Permanent Residence: Job Outcomes of Work Permit Holders. Wellington, Department of Labour.

Barrett, G.F. (2012). The Return to Cognitive Skills in the Australian Labour Market. Economic Record 88(280): 1-17.

Beach, C.M. and Worswick, C. (1993). Is There a Double Negative Effect on the Earnings of Immigrant Women? Canadian Public Policy 19(1): 36-53.

Bedford, R.D. and Poot, J. (2010). Changing Tides in the South Pacific: Immigration to Aotearoa New Zealand. In: U.A. Segal, D. Elliott and N.S. Mayadas (eds) Immigration Worldwide. New York, NY: Oxford University Press, pp. 257-273.

Bergerhoff, J., Borghans, L., Seegers, P.K. and van Veen, T. (2013) International Education and Economic Growth. IZA Journal of European Labor Studies 2: 3.

Borjas, G. (1987). Self-Selection and the Earnings of Immigrants. American Economic Review 77(4): 531-553.

Borjas, G. (2013). Labor Economics, 6th edition, McGraw Hill.

Boyd, C. (2003). Migrants in New Zealand: An Analysis of Labour Market Outcomes for Working Aged Migrants Using 1996 and 2001 Census Data. Wellington: New Zealand Department of Labour.

Card, D. (1999). The Causal Effect of Education on Earnings. Handbook of Labor Economics, Vol. 3, part A, pp. 1801-1863. Amsterdam: Elsevier.

Chiswick, B. (1978). The Effect of Americanization on the Earnings of Foreign-born Men. Journal of Political Economy 86(5): 897-921.

Chiswick, B. (1999). Are Immigrants Favourably Self-Selected? American Economic Review 89(2): 181-185.

Chiswick, B., and Miller, P. (2003). The Complementary of Language and Other Human Capital: Immigrant Earnings in Canada. Economics of Education Review 22(5): 469-480.

Chiswick, B., and Miller, P. (2009). The International Transferability of Immigrants' Human Capital. Economics of Education Review 28(2): 162-169.

Dumont, J.-C. and Lemaitre, G. (2008). Counting Foreign-Born and Expatriates in OECD Countries: A New Perspective. In: J. Raymer and Frans Willekens (eds) International Migration in Europe: Data, Models and Estimates. London: Wiley.

Duncan, N.T. (2008). Brain Drains, Brain Gains, and Migration Policies. In: J. Poot, B. Waldorf and van L. van Wissen (eds) Migration and Human Capital, Cheltenham UK: Edward Elgar, pp. 259-280.

Dustmann, C. and Glitz, A. (2011). Migration and Education. NORFACE Migration Discussion paper No. 2011-11, www.norface-migration.org

Dustmann, C. and Van Soest, A. (2002). Language and the Earnings of Immigrants. Industrial and Labour Relations Review 55(3): 473-489.

Dustmann, C., Fadlon, I. and Weiss, Y. (2011) Return Migration, Human Capital Accumulation and the Brain Drain. Journal of Development Economics 95(1): 58-67.

Earle, D. (2009). Skills, Qualifications and Wages: an Analysis from the Adult Literacy and Life Skills Survey. Wellington: Ministry of Education.

Education New Zealand (2012) Statement of Intent: 2012/2015. Welllington: Education New Zealand.

Ferrer, A, and Riddell, W.C. (2008). Education, Credentials, and Immigrant Earnings. Canadian Journal of Economics 41(1): 186-216.

Friedberg, R. (2000). You Can't Take It with You? Immigrant Assimilation and the Portability of Human Capital. Journal of Labor Economics 18(2): 221-251. 
Fujii, E.T. and Mak, J.(1983). On the Specification of the Income Equation for Immigrants. Southern Economic Journal 49(4): 1141-1146.

Gibson, J. and McKenzie, D. (2011). The Microeconomic Determinants of Emigration and Return Migration of the Best and Brightest: Evidence from the Pacific. Journal of Development Economics 95(1): 18-29.

Gibson, J. and McKenzie, D. (2012). The Economic Consequences of 'Brain Drain' of the Best and Brightest: Microeconomic Evidence from Five Countries. Economic Journal 122(560): 339-375.

Hammarstedt, M. and Shukur, G. (2006). Immigrants' Relative Earnings in Sweden - A Cohort Analysis. Labour 20(2): 285-323.

Heckman, J. (1979). Sample Selection Bias as a Specification Error. Econometrica 47: 153-161.

Holmlund, H., Lindahl, M., and Plug, E. (2011). The Causal Effect of Parents' Schooling on Children's Schooling: A Comparison of Estimation Methods. Journal of Economic Literature 49(3): 615651.

Leydesdorff, L. (2012). The Triple Helix of University-Industry-Government Relations. In: E. Carayannis and D. Campbell (eds.) Encyclopedia of Creativity, Innovation and Entrepreneurship. New York: Springer.

Li, P. (2001). The Market Worth of Immigrants’ Education Credentials. Canadian Public Policy 27(1): 23-38.

Lubotsky, D. (2007). Chutes or Ladders: A Longitudinal Analysis of Immigrant Earnings. Journal of Political Economy 115(5): 820-867.

Mayr, K. and Peri, G. (2008). Return Migration as a Channel of Brain Gain, NBER Working Paper 14039. Cambridge Mass.: National Bureau of Economic Research.

Mincer, J. (1958). Investment in Human Capital and Personal Income Distribution. Journal of Political Economy 66: 281-302.

New Zealand Immigration Service (2003a). Skilled Migrants: Labour Market Experiences. New Zealand Department of Labour Occasional Paper. Wellington: Department of Labour.

New Zealand Immigration Service (2003b). Migrants in New Zealand: An Analysis of 2001 Census Data. New Zealand Department of Labour Occasional Paper. Wellington: Department of Labour.

Poot, J. (1993). Adaption of Migrants in the New Zealand Labour Market. International Migration Review, 27(1), 121-139.

Poot, J. (2013). Global Trade and International Migration. In I. Ness (ed.) The Encyclopedia of Global Human Migration. Blackwell Publishing. DOI: 10.1002/9781444351071.wbeghm255

Poot, J. and Stillman, S. (2010). The Importance of Heterogeneity When Examining Immigrant Education-Occupation Mismatch: Evidence from New Zealand. IZA Discussion Paper 5211. IZA Institute for the Study of Labor, Bonn.

Poot, J., Nana, G., and Philpott, B. (1988). International Migration and the New Zealand Economy: A Long-Run Perspective. Wellington: Institute of Policy Studies, Victoria University of Wellington.

Soon, J.-J. (2012). Home is Where the Heart Is? Factors Determining International Students' Destination Country upon Completion of Studies Abroad. Journal of Ethnic and Migration Studies 38(1): 147-162.

Spoonley, P. and Bedford, R. (2012). Welcome to our World? Immigration and the Reshaping of New Zealand. Palmerston North: Dunmore Press.

Statistics New Zealand. (2004). Degrees of Difference: The Employment of University Qualified Immigrants in New Zealand. Wellington: Statistics New Zealand.

Stillman, S., and Mare, D. (2009). The Labour Market Adjustment of Immigrants in New Zealand. Economic Impacts of Immigration: Working Paper Series. Wellington: Department of Labour.

Winkelmann, L. and Winkelmann, R.(1998). Immigrants in New Zealand Labour Market: A Cohort Analysis Using 1981, 1986 and 1996 Census Data. Labour Market Bulletin 1998(1\&2): 34-70. 
Woolf, J. (2010). The Economic and Social Outcomes of Children of Migrants in New Zealand. Wellington: Statistics New Zealand.

Zax, J.S. and Rees, D.I. (2002). IQ, Academic Performance, Environment, and Earnings. Review of Economics and Statistics 84(4): 600-616.

Zodgekar, A. (1990). British Emigrants to New Zealand: Their Motives and Expectations. International Migration. 28(4): 427-441. 
Table 1: Means of variables used in multivariate analysis

\begin{tabular}{l|rr|rr}
\hline & New Zealand born & \multicolumn{2}{|c}{ Foreign Born } \\
\hline & Male & Female & Male & Female \\
\hline Hourly earnings & $\$ 25.53$ & $\$ 23.81$ & $\$ 26.05$ & $\$ 23.57$ \\
Annual income & $\$ 66,816$ & $\$ 48,178$ & $\$ 66,363$ & $\$ 53,676$ \\
Age & 39.51 & 40.60 & 40.14 & 40.48 \\
Years since migration & $\mathrm{N} / \mathrm{A}$ & $\mathrm{N} / \mathrm{A}$ & 16.96 & 17.74 \\
Has children & $46.40 \%$ & $41.19 \%$ & $36.76 \%$ & $41.12 \%$ \\
Household size & 2.96 & 2.93 & 3.46 & 3.23 \\
Has physical health problems & $15.09 \%$ & $18.60 \%$ & $11.31 \%$ & $17.03 \%$ \\
NZ European ethnicity & $78.73 \%$ & $80.84 \%$ & $18.51 \%$ & $23.60 \%$ \\
Maori ethnicity & $14.32 \%$ & $13.05 \%$ & $1.03 \%$ & $0.49 \%$ \\
Pacific Island ethnicity & $3.94 \%$ & $4.07 \%$ & $23.14 \%$ & $19.95 \%$ \\
Asian ethnicity & $0.50 \%$ & $0.21 \%$ & $27.25 \%$ & $26.28 \%$ \\
Other ethnicity & $2.51 \%$ & $1.82 \%$ & $30.08 \%$ & $29.68 \%$ \\
Hours worked per year & 2100 & 1603 & 2017 & 1707 \\
Years in current job & 7.56 & 6.11 & 5.96 & 5.30 \\
Works part-time & $8.01 \%$ & $33.03 \%$ & $9.51 \%$ & $28.85 \%$ \\
Innate ability score (benchmark =0) & -11.34 & 10.86 & -2.17 & 0.70 \\
Lives in rural area & $13.99 \%$ & $11.09 \%$ & $6.68 \%$ & $5.84 \%$ \\
Mother has post-secondary education & $20.90 \%$ & $24.63 \%$ & $29.31 \%$ & $26.04 \%$ \\
Father has post-secondary education & $32.21 \%$ & $32.91 \%$ & $42.30 \%$ & $48.14 \%$ \\
Receives investment income & $27.96 \%$ & $26.11 \%$ & $25.30 \%$ & $21.53 \%$ \\
Receives social security & $19.33 \%$ & $30.66 \%$ & $16.25 \%$ & $24.71 \%$ \\
Household size when female & $\mathrm{n} . \mathrm{a}$. & 3.08 & $\mathrm{n} . \mathrm{a}$. & 3.41 \\
Number of observations & 1,194 & 1,425 & 389 & 411 \\
& & & &
\end{tabular}


Table 2: Education characteristics

\begin{tabular}{|c|c|c|c|c|c|}
\hline & & \multicolumn{2}{|c|}{ New Zealand born } & \multicolumn{2}{|c|}{ Foreign born } \\
\hline & & male & female & male & female \\
\hline \multirow{6}{*}{ 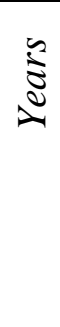 } & Total years of education & 13.23 & 13.47 & 14.26 & 14.66 \\
\hline & Years of New Zealand education (incl. 0) & 13.00 & 13.01 & 3.89 & 3.63 \\
\hline & Years of New Zealand education (excl. 0) & 13.04 & 13.04 & 8.34 & 7.93 \\
\hline & Years of education abroad (incl. 0) & 0.17 & 0.13 & 10.52 & 10.49 \\
\hline & Years of education abroad (excl. 0) & 4.06 & 2.86 & 12.69 & 12.28 \\
\hline & Percentage with foreign education & $3.85 \%$ & $4.98 \%$ & $83.29 \%$ & $84.91 \%$ \\
\hline \multirow{14}{*}{ 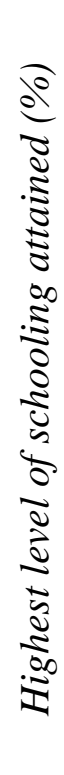 } & Up to Form 5/Year 11 & $27.05 \%$ & $24.98 \%$ & $19.28 \%$ & $13.87 \%$ \\
\hline & Form 6 or $7 /$ Year 12 or 13 & $14.74 \%$ & $16.84 \%$ & $13.62 \%$ & $15.57 \%$ \\
\hline & Total with school only qualifications & $41.79 \%$ & $41.82 \%$ & $32.90 \%$ & $29.44 \%$ \\
\hline & Level 1, 2 or 3 certificate & $16.83 \%$ & $14.11 \%$ & $9.77 \%$ & $9.49 \%$ \\
\hline & Level 4 certificate & $16.92 \%$ & $6.74 \%$ & $12.08 \%$ & $4.62 \%$ \\
\hline & Level 5,6 or 7 certificate & $8.63 \%$ & $15.86 \%$ & $11.83 \%$ & $18.00 \%$ \\
\hline & Bachelor's degree & $8.04 \%$ & $11.23 \%$ & $14.40 \%$ & $15.57 \%$ \\
\hline & Professional degree & $1.26 \%$ & $1.82 \%$ & $2.06 \%$ & $2.92 \%$ \\
\hline & $\begin{array}{l}\text { Total post-secondary undergraduate } \\
\text { qualification }\end{array}$ & & & $50.14 \%$ & \\
\hline & Bachelor's degree with honours or post-grad dip. & $4.10 \%$ & $6.67 \%$ & $7.20 \%$ & $10.71 \%$ \\
\hline & Master's degree & $1.59 \%$ & $1.47 \%$ & $7.97 \%$ & $7.06 \%$ \\
\hline & $\mathrm{PhD}$ & $0.84 \%$ & $0.28 \%$ & $1.80 \%$ & $2.19 \%$ \\
\hline & Total postgraduate qualification & $6.53 \%$ & $8.42 \%$ & $16.97 \%$ & $19.96 \%$ \\
\hline & Number of observations & 1,194 & 1,425 & 389 & 411 \\
\hline
\end{tabular}


Table 3: The return to total education for males and females

\begin{tabular}{|c|c|c|c|}
\hline Regression variables & Pooled & Males & Females \\
\hline \multirow[t]{2}{*}{ Foreign born } & $-0.152 * * *$ & $-0.114 *$ & $-0.195 * * *$ \\
\hline & $(0.038)$ & $(0.053)$ & $(0.055)$ \\
\hline \multirow[t]{2}{*}{ Years since migration } & $0.004^{* *}$ & 0.003 & $0.005^{*}$ \\
\hline & $(0.002)$ & $(0.002)$ & $(0.002)$ \\
\hline \multirow[t]{2}{*}{ Age } & $0.055^{* * *}$ & $0.061 * * *$ & $0.050 * * *$ \\
\hline & $(0.006)$ & $(0.009)$ & $(0.008)$ \\
\hline \multirow[t]{2}{*}{ Age $^{2} / 100$} & $-0.059 * * *$ & $-0.063 * * *$ & $-0.055^{* * *}$ \\
\hline & $(0.007)$ & $(0.010)$ & $(0.010)$ \\
\hline \multirow[t]{2}{*}{ Total years of education } & $0.062 * * *$ & $0.057 * * *$ & $0.069 * * *$ \\
\hline & $(0.004)$ & $(0.005)$ & $(0.005)$ \\
\hline \multirow[t]{2}{*}{ Constant } & $1.199 * * *$ & $1.152 * * *$ & $1.215^{* * *}$ \\
\hline & $(0.121)$ & $(0.170)$ & $(0.173)$ \\
\hline$R^{2}$ & 0.117 & 0.133 & 0.110 \\
\hline$n$ & 3,414 & 1,582 & 1,832 \\
\hline
\end{tabular}

Notes: The dependent variable is natural logarithm of hourly wages. Standard errors in parenthesis. *** Significant at $1 \%$, ** significant at $5 \%$ and * Significant at $10 \%$ 
Table 4: The returns to foreign and domestic education for males and females

\begin{tabular}{|c|c|c|c|}
\hline Regression variables & Pooled & Males & Females \\
\hline \multirow[t]{2}{*}{ Foreign born } & -0.058 & -0.064 & -0.093 \\
\hline & $(0.076)$ & $(0.107)$ & $(0.106)$ \\
\hline \multirow[t]{2}{*}{ Years since migration } & 0.002 & 0.001 & 0.003 \\
\hline & $(0.002)$ & $(0.003)$ & $(0.003)$ \\
\hline \multirow[t]{2}{*}{ Age } & $0.049 * * *$ & $0.057 * * *$ & $0.039 * * *$ \\
\hline & $(0.007)$ & $(0.010)$ & $(0.010)$ \\
\hline \multirow[t]{2}{*}{ Age $^{2} / 100$} & $-0.056^{* * *}$ & $-0.062 * * *$ & $-0.047 * * *$ \\
\hline & $(0.009)$ & $(0.013)$ & $(0.012)$ \\
\hline \multirow[t]{2}{*}{ Years of NZ education } & $0.040^{* * *}$ & $0.026 * * *$ & $0.046^{* * *}$ \\
\hline & $(0.004)$ & $(0.006)$ & $(0.006)$ \\
\hline \multirow[t]{2}{*}{ Years of education abroad } & $0.037 * * *$ & $0.025 * *$ & $0.042 * * *$ \\
\hline & $(0.006)$ & $(0.008)$ & $(0.008)$ \\
\hline \multirow[t]{2}{*}{ Number of years in current job } & $0.012 * * *$ & $0.012 * * *$ & $0.009 * * *$ \\
\hline & $(0.002)$ & $(0.002)$ & $(0.003)$ \\
\hline \multirow[t]{2}{*}{ Measure of innate ability } & $0.025 * *$ & $0.042 * *$ & 0.015 \\
\hline & $(0.009)$ & $(0.013)$ & $(0.013)$ \\
\hline \multirow[t]{2}{*}{ Constant } & $1.549 * * *$ & $1.574 * * *$ & $1.622^{* * *}$ \\
\hline & $(0.154)$ & $(0.215)$ & $(0.227)$ \\
\hline$R^{2}$ & 0.175 & 0.200 & 0.190 \\
\hline$n$ & 2,874 & 1,296 & 1,551 \\
\hline
\end{tabular}

Notes: The dependent variable is the natural logarithm of hourly wages. Standard errors in parenthesis. *** Significant at $1 \%$, ** significant at $5 \%$ and * Significant at $10 \%$.

Each regression also controls for an urban or rural location of the household, the industry in which the person works, the presence of children, health status, and the education level of parents. 
Table 5: The returns to New Zealand and foreign education for New Zealand born and foreign born

\begin{tabular}{|c|c|c|c|c|}
\hline \multirow[b]{2}{*}{ VARIABLES } & \multicolumn{2}{|c|}{ NZ born } & \multicolumn{2}{|c|}{ Foreign born } \\
\hline & lnwage & selection & lnwage & selection \\
\hline Male & $0.139 * * *$ & $-0.279 * * *$ & $0.103^{* *}$ & -0.226 \\
\hline \multirow{2}{*}{ Rural } & -0.011 & $-0.369 * * *$ & $0.164^{*}$ & $-0.331^{* *}$ \\
\hline & $(0.041)$ & $(0.056)$ & $(0.099)$ & $(0.137)$ \\
\hline \multirow[t]{2}{*}{ Household size } & 0.006 & -0.000 & -0.011 & 0.042 \\
\hline & $(0.010)$ & $(0.020)$ & $(0.015)$ & $(0.031)$ \\
\hline \multirow[t]{2}{*}{ Ill health } & $0.059^{*}$ & $-0.221 * * *$ & -0.022 & -0.127 \\
\hline & $(0.035)$ & $(0.049)$ & (0.069) & $(0.092)$ \\
\hline \multirow[t]{2}{*}{ Age } & $0.038 * * *$ & $0.055^{* * *}$ & $0.030^{*}$ & $0.104^{* * *}$ \\
\hline & $(0.007)$ & $(0.010)$ & $(0.016)$ & $(0.019)$ \\
\hline \multirow[t]{2}{*}{$\mathrm{Age}^{2} / 100$} & $-0.041 * * *$ & $-0.084 * * *$ & -0.026 & $-0.136 * * *$ \\
\hline & $(0.009)$ & $(0.012)$ & $(0.020)$ & $(0.023)$ \\
\hline \multirow[t]{2}{*}{ Years of NZ education } & $0.024 * * *$ & $0.035^{* * *}$ & $0.028 * * *$ & 0.018 \\
\hline & $(0.005)$ & $(0.007)$ & $(0.009)$ & $(0.011)$ \\
\hline \multirow[t]{2}{*}{ Years of education abroad } & $0.033^{* *}$ & -0.003 & $0.018^{* *}$ & $0.021^{* *}$ \\
\hline & $(0.014)$ & $(0.021)$ & $(0.009)$ & $(0.011)$ \\
\hline Years since migration & & & $\begin{array}{c}-0.003 \\
(0.003)\end{array}$ & \\
\hline \multirow[t]{2}{*}{ Receives investment income } & & $-0.153^{* * *}$ & & $\begin{array}{c}-0.142 * \\
(0.080)\end{array}$ \\
\hline & & $\begin{array}{c}(0.045) \\
-0.122 * * *\end{array}$ & & $-0.115^{* * *}$ \\
\hline Interaction of gender and household size & & $(0.026)$ & & $(0.041)$ \\
\hline \multirow{2}{*}{ Receives social security } & & $-0.737 * * *$ & & $-0.761 * * *$ \\
\hline & & $(0.047)$ & & $(0.092)$ \\
\hline \multirow[t]{2}{*}{ Maori ethnicity } & & -0.018 & & -0.040 \\
\hline & & $(0.063)$ & & $(0.431)$ \\
\hline \multirow[t]{2}{*}{ Pacific Island ethnicity } & & 0.073 & & -0.105 \\
\hline & & $(0.105)$ & & $(0.123)$ \\
\hline \multirow[t]{2}{*}{ Asian ethnicity } & & -0.318 & & $-0.409 * * *$ \\
\hline & & $(0.278)$ & & $(0.108)$ \\
\hline \multirow[t]{2}{*}{ Other ethnicity } & & $-0.234^{*}$ & & $-0.185^{*}$ \\
\hline & & $(0.122)$ & & $(0.101)$ \\
\hline \multirow[t]{2}{*}{ Number of years in current job } & $0.011^{* * *}$ & & $0.012^{* * *}$ & \\
\hline & $(0.002)$ & & $(0.004)$ & \\
\hline \multirow[t]{2}{*}{ Measure of innate ability } & 0.007 & & $0.032 *$ & \\
\hline & $(0.010)$ & & $(0.018)$ & \\
\hline \multirow[t]{2}{*}{ Mother has post-secondary education } & -0.007 & & -0.018 & \\
\hline & $(0.031)$ & & $(0.055)$ & \\
\hline \multirow[t]{2}{*}{ Father has post-secondary education } & 0.028 & & $0.152^{* * *}$ & \\
\hline & $(0.028)$ & & $(0.050)$ & \\
\hline \multirow[t]{2}{*}{ Heckman’s lambda } & & $-0.181^{* * *}$ & & $-0.320 * * *$ \\
\hline & & $(0.064)$ & & (0.116) \\
\hline \multirow[t]{2}{*}{ Constant } & $2.291 * * *$ & $-0.702 * * *$ & $2.570^{* * *}$ & $-1.682^{* * *}$ \\
\hline & $(0.176)$ & $(0.221)$ & $(0.405)$ & $(0.401)$ \\
\hline Observations & 2,619 & 4,661 & 800 & 1,592 \\
\hline
\end{tabular}

Notes: The dependent variable is the natural logarithm of hourly wages. The coefficients are estimated with Heckman's twostep procedure. Standard errors in parenthesis. ${ }^{* * *}$ Significant at $1 \%,{ }^{* *}$ significant at $5 \%$ and ${ }^{*}$ Significant at $10 \%$. Estimated regional effects are not included in the table. 
Figure 1: Total years of education for New Zealand born and foreign born

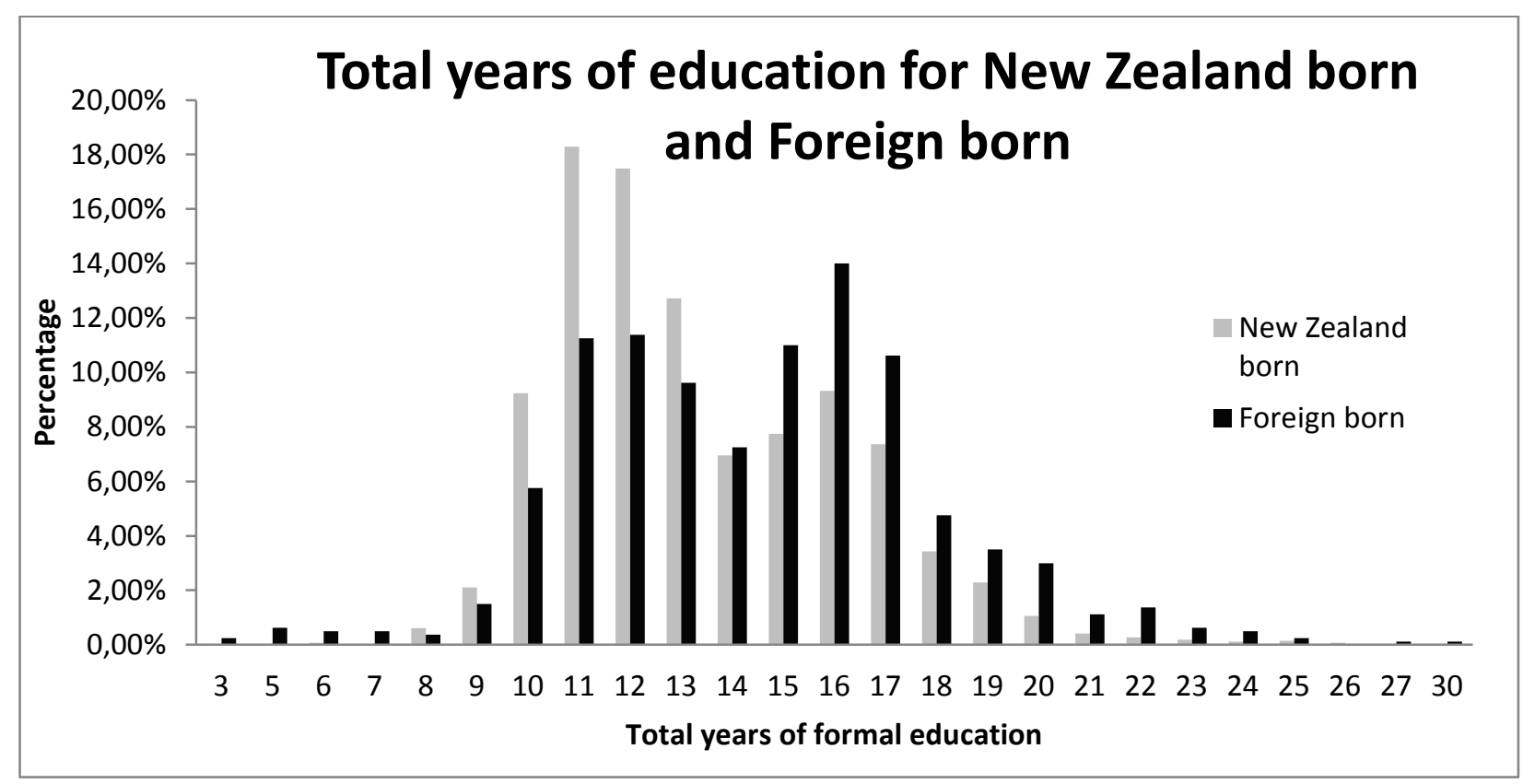

